\title{
A görkorcsolyázás története III.
}

\section{History of roller-skateing III.}

Összefoglaló: A görkorcsolyázás története I. ${ }^{1}$ és II. ${ }^{2}$ című tanulmányban foglalkoztunk a görkorcsolyázás hőskorával, feltalálókkal, találmányokkal, görkorcsolyával végzett korai rekreációs lehetőségekkel, helyekkel, az egy-, két-, három-, sok- kerekü görkorcsolyákkal, valamint egyéb érdekes ötlettel, amelyeket a 19. század vége felé megjelent ebben a müfajban. Jelen összefoglaló műben foglalkozunk az 1800-as évek végének tengeren túli és európai görkoris életével, újabb találmányokkal. Tárgyaljuk a korai XX. század elejének görkorcsolyát érintő híreit. A világháborúk utáni lassú, majd a 70-es, 80-as évek felpörgő eseményeit, egészen az Olsen fivérek tevékenységének köszönhető, egysoros görkorcsolya köztudatba robbanását, és a lábra szerelhető gördülő eszközök azóta is töretlenül tartó virágkorát. Bemutatjuk hogyan alakultak ki és épültek fel a legjelentősebb görkorcsolya sport irányzatok.

Kulcsszavak: görkorcsolya, görkorcsolyázás, egysoros, párhuzamos, történet, Rollerblade, roller derby, roller polo

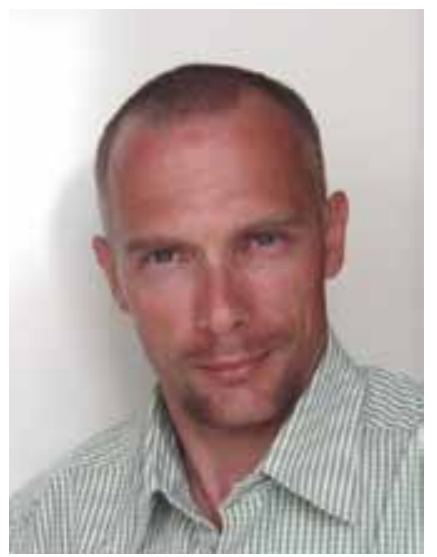

Szerző:
BÉRES SÁNDOR Ph.D. Egyetemi docens

Eszterházy Károly Főiskola, Testnevelés és Sporttudományi Intézet Eger
Miután LeVANT RICHARDSON 1884-es szabadalmával acél golyóscsapágyakkal látta el a görkorcsolya kerekeket, szinte azonnal megszületett egy új őrület. $A$ korszakalkotó változás ellenére nyilvánvalóan voltak még hiányosságok, ami a korai görkorcsolyák szerkezetét illeti. Égető volt a jobb gördülés érdekében további lépéseket tenni. A buxusfát pl., melyből a kerekek készültek Perzsiából és Törökországból rendelték, de azok hamar elhasználódtak, ráadásul a nyersanyag amúgy is magas ára, egyre csak emelkedett az 1800-as évek végén - 30\$-ról, $120 \$$-ra tonnánként. Csak összehasonlítás képpen egy Muncie Plated görkorcsolya akkoriban $6 \$$, egy átlagos $4 \$$ körül volt ${ }^{3}$.
A századfordulóhoz közeledve ismét kicsit fellendül „cyclespatins", azaz az egysoros görkorcsolyák használata, melyek e periódus után már csak 1990-es években, a „rollerblade-ek” megjelenésével kerülnek újra komolyabban az érdeklődés középpontjába ${ }^{4}$. Az ebben a korban használt görkorcsolyák a holland kisváros, Hindeloopen korcsolya múzeumában tekinthetők meg.

A görkorcsolya „fejlesztési láz” tovább gyürüzik. 1900-ban a Peck \& Snyder Company soros kétkerekü korit szabadalmaztatott. 1905-ben, New Yorkban jelenik meg az első szabályozható, szorító szíjjal szerelt görkorcsolya. A Roller Skate Company 1910-ben soros, háromkerekü, bőrcipővel ellátott változattal állt elő, mely az 1930-as évekre már nagy népszerüségnek örvend. Ugyanekkor a Best-Ever Built Skate Company legyárt egy szintén három kerekü soros görkorcsolyát, mely egészen közel volt a talajhoz ${ }^{5}$.

\section{A GÖRKORCSOLYÁZÁS SZÍNTEREI}

Az XIX. század végén a jégkorcsolyázni vágyóknak a természetes helyeken, tavakon, folyókon kívül épített pályák is rendelkezésre álltak, bár ezeket is csak télen, a fagy beálltával

\footnotetext{
1 (Béres, A görkorcsolyázás története I., 2012)

2 (Béres, A görkorcsolyázás története II., 2012)

${ }^{3}$ (Rink, 2011)

${ }^{4}$ (Bonnefon, 2005)

${ }^{5}$ (National Museum of Roller Skating, 2010)
} 
tudták használatba venni. Jégpályák mesterséges készítésére a hütőcsöves rendszert már 1865-ben feltalálták, de csak jóval később kezdték el alkalmazni a technológiát, mert akkoriban a jégkészítés nagyon drága volt.

A nagy jégkorcsolya pályák mellett - mint amilyen pl. a párizsi „Le Palais de Glace” is volt - számos görkorcsolyapálya nyílt az Egyesült Államokban és Európában.

Az első görkorcsolyapályát még PLIMPTon elött 1866-ban Izlandon, a Newport Atlantik Hotelben nyitották meg. A kétezer négyzetméternél nagyobb, luxus pályákon való gurulást általában csak a tehetősebbeknek engedhették meg maguknak.

Ezzel együtt a görkorcsolyázás a század második felére Európában kiment a divatból és nem sokkal később 1880-ra már csak egy pálya létezett Párizsban. A „Le Palais de Glace” (1. ábra) azonban a $X X$. századig nyitva maradt.

Amerikában „ha meg tudod csinálni a táncparketten, meg tudod csinálni a korival is" jelmondattal még több, nagyobb és jobb görkorcsolya ring épült, amelyekhez profi instruktorokat szerződtettek. A legtöbb ringhez galériás ülöhelyeket építettek, így mások is nézhették a görkorcsolyázókat. $A$ jobb helyeken külön személyzet kötötte be a kori cipőket és teljes zenekarok szolgáltatták a zenét. Hoki és póló csapatok játszottak az odalátogatókkal, mely folyamat már 1870 -ben elkezdődött ${ }^{8}$.

Az 1890-es évek kerékpár őrülete a görkorcsolya iránti rajongást háttérbe szorította. Ez azonban nem tartott hosszú ideig, hiszen 1902-ben megépült néhány nagyszerü, új görkorcsolya ring. Ilyen volt például a 7000 ! fővel nyitóestét tartó, lenyügöző, hatalmas Chicago Coliseum (2. ábra). Még ebben az

\section{VIII}

\section{Abstract:}

In the study entitled The History of Roller Skating I. and II. we discussed the early age of roller skating, the inventors, inventions, the recreational aspects of early activities done with roller skate, special places, the roller skate itself especially the one-, two-, three-, and many wheeled form of it, and other interesting ideas that occured in the late 19th century in that field. In this comprehensive study we present the overseas and European roller skate life and some other inventions of that age. We discuss the roller skate news of the early 20th century, the slow development of post world war times and the acceleration of events in the seventies and eighties due to the Olsen brothers' activity, the rapid spread of inline skates and the golden age of rolling devices fastened to shoes. We present the evolution and building up of the most important roller skate sport sections. Keywords: skating, roller-skate, inline-skate, history, Rollerblade, roller derby, roller hockey évben az Amerikai Nemzeti Görkorcsolya Szövetség (National Skating Association) megszervezte a nemzetközi style back to rollerskating-et, melynek elnevezése sugallja annak célját.

Ebben a korszakban a görkorcsolyázás első nagy virágkorát érte Amerikában. Voltak, akik a munkahelyre is görkorcsolyával mentek. Pár klubnak privát görkorcsolya pályái voltak és a speed és endurance korizás volt a sláger. A források szerint az egyik gyorsasági görkorcsolya bajnokot HARLEY DAVIDSONNAK hívták, de az úriembernek nem volt köze a híres 1903-ban alapult amerikai motorgyárhoz, már csak azért sem, mert a név a két alapító tag nevének összetételeként jött létre.

Az 1900-as években több görkorcsolya szövetség létesült és a versenyek és kiállítások egymást érték, beleértve az elitnek rendezett díszelöadásokat is, akik közül ugyancsak sokan görkorcsolyáztak. A görkorcsolya láz oly mértékeket öltött, hogy a new york-i Vaudeville színház (3. ábra) komplett, görkorcsolyára tervezett előadásokat vitt színre, melyben volt komédia görkorizás, gólyalábas-, székes-, akrobatikus görkorcsolyázó mutatvány, hordó ugrások és páros görtánc is.
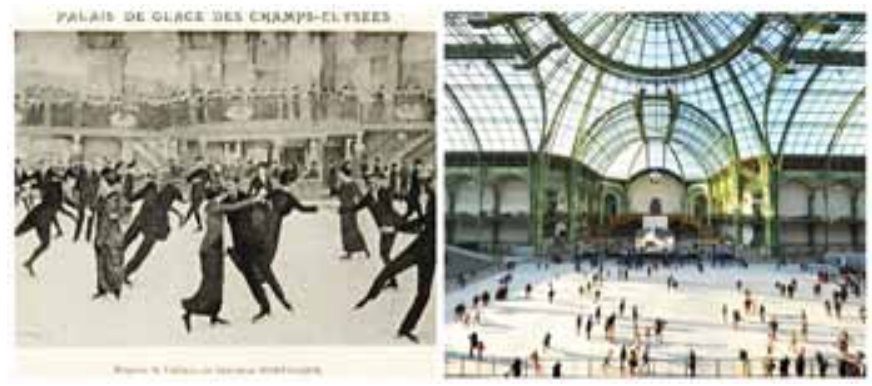

1. ábra Le Palais de Glace, Párizs a ChampsElysees-n $(1890)^{6,7}$
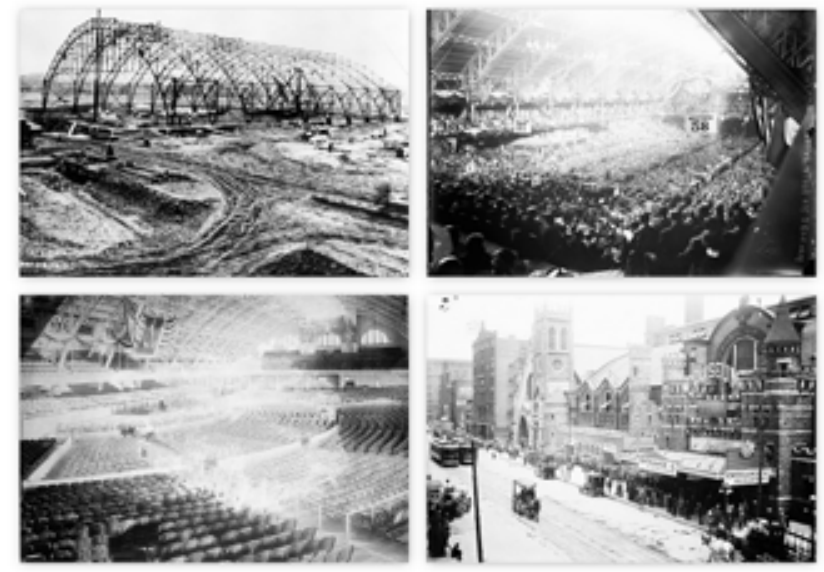

2. ábra A Chicago Coliseum $1513 \mathrm{~S}$. Wabash Ave. $(1900-1982)^{9,10,11,12}$

\footnotetext{
${ }^{6}$ http://www.yaneff.com/images/thumbnails/palais_de_glace.jpg

${ }^{7}$ http://www.sortiraparis.net/images/800/8412/85962-le-grand-palais-desglaces-8.jpg

${ }^{8}$ (Rink, 2011)

${ }^{9}$ http://3.bp.blogspot.com/-G_VEa2DelUw/UGyirnmv1DI/AAAAAAAAAbs/ v49RsIsdFRg/s1600/Colisteele3.jpg

${ }^{10} \mathrm{http} / / /$ upload.wikimedia.org/wikipedia/commons/d/df/Republican_National_ Convention_1912.jpg

${ }^{11} \mathrm{http}$ ://upload.wikimedia.org/wikipedia/commons/0/03/Chicago_Coliseum.jpg

12 http://www.vanishedamericana.com/wp-content/uploads/2009/09/ChicagoColiseum.jpg
} 
A ring vezetők egyetlen célja a divathullám meglovagolásával a lehető legjobb piaci pozíció megszerzése volt és ezért semmi sem volt elég drága. Milwaukee-ben például $50 \$$ és szállodai ellátást ajánlott fel HADDIE BALDWIN és W. McGRATH annak, aki elmegy az első teljesen görkorcsolyás házassági ceremóniára, ahova végül ezrek mentek, hogy megnézzék.

\section{A GÖRKORCSOLYA VERSENYEK ÉS JÁTÉKOK Állóképességi és speed versenyek}

A görkorcsolyázás növekvő népszerüsége az Egyesült Államokban oda vezetett, hogy hivatalosan állóképességi versenyeket kezdtek el szervezi, miután 1884-ben VICTOR W. CLOUGH

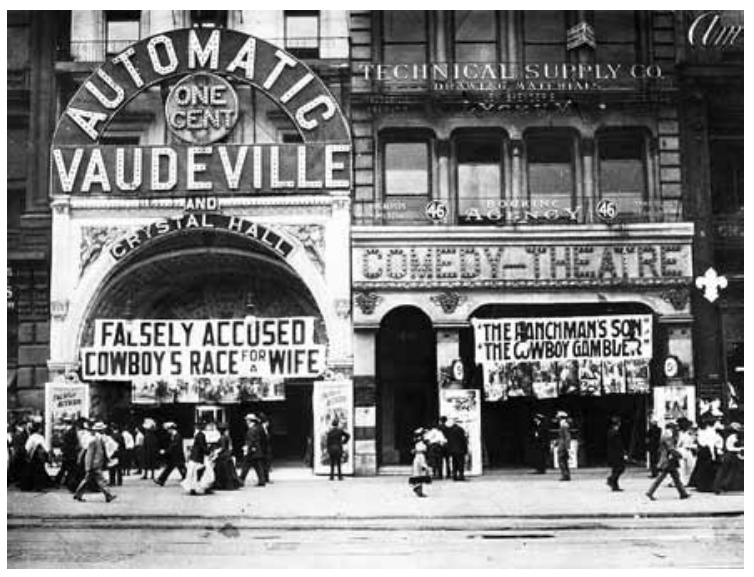

3. ábra A new york-i Vaudeville Theatre 1905-ből. ${ }^{13}$

100 mérföldet $(160 \mathrm{~km})$ korcsolyázott, közel 10 óra alatt az Illinois állambeli Geneseo-ban.

1885-ban egy hat napos „menj-ahogy-tetszik” („Go-as-youplease") versenyen, melyet a new york-i Old Madison Square Garden-ben rendeztek (4. ábra), 36 korcsolyázó versengett a fődíjként megjelölt $500 \$$-ért. A hat napos verseny végül két halálos áldozatot követelt. Úgy a nyertes WILLIAM DonovaN, mint társa JOSEPH COHEN meghalt nem sokkal azután, hogy a versenyt befejezték.

Donovan egyébként $1745 \mathrm{~km}$-t görkorcsolyázott ${ }^{14}$. Ahogy a korabeli 1885. április 11.-én megjelent, New York Times ötödik oldalán beszámolnak róla $A$ görkorcsolya áldozata címmel: „,... az utolsó torna győztese, Donovan halála. A megeröltetéstől és betegségtől elgyengülve - a támogató szerint a gyerek apja túldolgoztatta..." Bár a nyomozás Cohen-ék halálát illetően egy törvényi ajánlással végződött, mely megtiltaná, hogy a görkorcsolya tevékenység ne tarthasson tovább, mint 4 óra, ám a hat napos versenyt 1885 májusára már újból kiírták.

A görkorcsolya versenyek népszerüsége továbbra is megmaradt beleértve az állóképességi versenyeket is és azok folytatódtak a korai $X X$. században is. Ezekre rendszerint amatör résztvevők neveztek, de jelen voltak a profi korcsolyázók, melyek közül néhányan csapatban indultak. A gyorsasági görkorcsolya rendezvények, a néhány ilyen eseményen lezajló szabálytalanság következményeként - melybe beletartoznak az akasztások, gáncsolások és lökések - olyan hírnévre tettek szert, mely nem igazán szolgálta e sport létjogosultságát. $A z$
Amerikai Nemzetközi Korcsolya Szövetség (The International Skating Union of America) 1907-ben egy saját versenyzőt nevezett ki az elnökségi posztra válaszként. $E$ regionális egyesü-

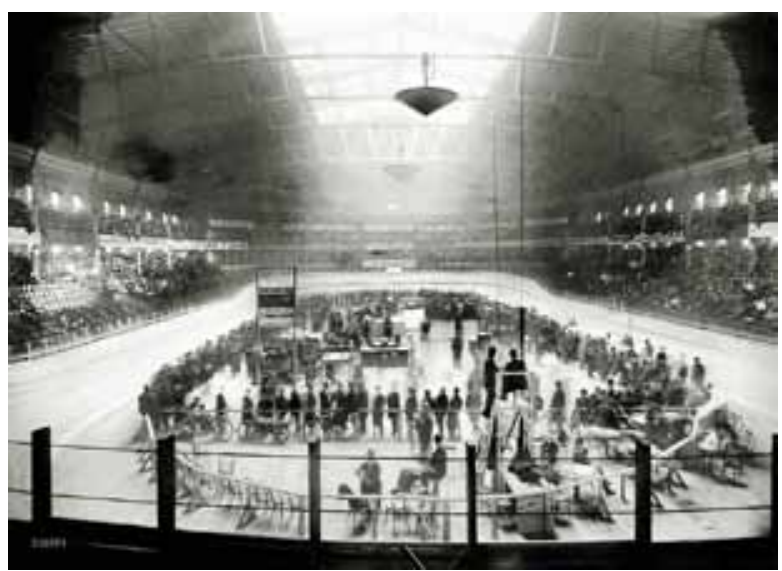

4. ábra Az Old Madison Square Garden, New York, USA, 1908 döntött pálya kialakítása egy hat napos kerékpár versenyen. ${ }^{16}$

leti hálózat 20 évig állt fenn, a bajnoki versenyek megszervezésének feladatával ill. olyan szabályok kialakításával, melyek lényege az erőszakos versengés megfékezése ${ }^{17}$. Az első hivatalos, amatör gyorsgörkorcsolya bajnokságot 1937 áprilisában, Detroitban a Gardens pályán rendezték meg.

Habár a gáncsolás és a lökdösődés nem volt engedélyezett bizonyos versenyeken, a népszerü gyorsasági és állóképességi viadalokon továbbra is dívott élni ezekkel az „eszközökkel”, úgy a sík, mint a döntött körpályákon az évszázad első három évtizedében.

A versenyek között volt egy 8,5 mérföldes roller maraton, melyet 1908-ban rendezett egy csoport chicagoi (Illinois) ring tulaj. A 24 órás állóképességi bajnokságot Milwaukee-ben (Wisconsin) tartották 1913-ban, és a 24 órás döntött pályás versenyt az Old Madison Square Gardenben, 1914-ben. A New York Times megjegyezte, hogy „... a nagyszámú nézőközönség rendkívüli módon élvezte az eseményt bevezető elő-versenyeken a hirtelen sprinteket és a bukásokat...".

\section{Roller hockey, roller polo ${ }^{18}$}

A villámgyors akciókat és a csapatjátékot kombinálva a mai szemlélö is könnyen belátja, hogy a roller hockey miért lett, lehetett a legdinamikusabban növekvő sport a földön. A roller hockey, vagy más néven roller polo 1878-ban indult útjára a londoni Denmark görkorcsolya ringböl. Az első verseny után nem sokkal, 1882-ben Daytonban már megrendezik a sportág első komoly nemzetközi versenyét is.

Az 1880-as években különböző közép-nyugat amerikai városok alapítottak néhány csapatot és jéghokiból átvett szabályokkal kialakították saját szabályrendszerüket. A résztvevők

\footnotetext{
${ }^{13}$ (Granger, 2013)

${ }^{14}$ (Rink, 2011)

${ }^{15}$ (Wikipedia, 2012)

${ }^{16}$ (Fixed Gear Gallery, 2013)

17 (Wikipedia, 2012)

${ }^{18}$ (National Museum of Roller Skating, 2010)
} 
begörbített végü botokkal játszottak, melyeket bizonyos helyeken egyszerüen csak botnak hívtak és a lábukra korabeli quad korcsolyákat húztak.

A játékot két egymás ellen felállt csapat játszotta úgy, hogy megpróbáltak egymás hálóval ellátott „ketrecébe” gólt lőni, az aktuálisan használt, labdával vagy koronggal. Az a csapat nyerte a játékot, amelyik a legtöbb gólt érte el. Akkoriban minden csapat 5-5 játékosból állt - a centerből, a két csatárból, egy halfback-böl és egy quarterbackböl.

Az amerikai roller hockey játék hamarosan három divízióra oszlott. A hardball, az Észak-Amerikai, és a korong hockey. Habár a kivitelezést illetően mind más, mégis sokban hasonlítanak egymáshoz. Mind a három formát két támadóval, két védővel és egy kapussal játsszák.

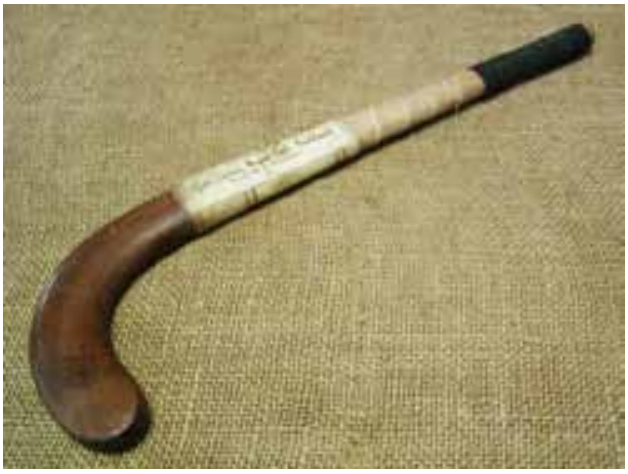

5. ábra Roller hockey ütő a korai évekböl - miniatür, de arányos utánzat az eBay-röl. ${ }^{19}$

A korongos verziót a jégkorong szabályaival, hoki ütővel és jégkoronggal játsszák.

Az észak-amerikai stílus nagyon hasonlít a korongos verzióra, de egy puhább labdával üzik, mely biztonságosabb a játékosok szempontjából.

A hardball változatot kemény, fekete, parafa/gumi kompozit labdával űzik, melyet rövid, ívben görbülő végü fa ütőkkel terelnek (canes - sétabot). Az soros görkorcsolyával játszott roller hockey jellegének leginkább illő a hardball-t fogadták el és endeznek nemzetközi versenyeket, ugyanakkor 1961-ben rendezték meg a roller hockey első quad görkorcsolyával üzött nemzetközi bajnokságát, melyben napjainkban a spanyol válogatott a legjobb.

A professzionális roller hockey 1991-ben indult útjára, mikor egy csoport beruházó megalapította a Roller Hockey's Interna-

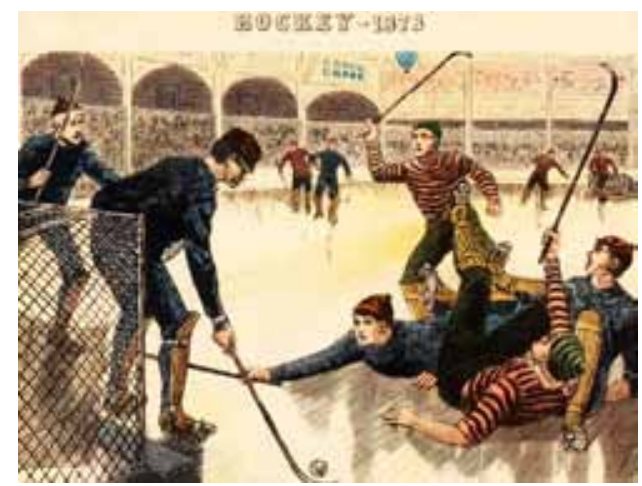

6. ábra A roller polo korabeli ábrázolása $(1878)^{20}$ tional-t. Az RHI csapatokat alakított ki különböző városokban Amerika szerte és játékosokat válogatott az amatőr szervezetekböl és hivatalos profi jégkorongozók közül. A liga 1994-ben ért a csúcsra 24 csapattal, majd némileg visszaesett a népszerüsége. Érdekesség, hogy a new jersey-i Rockin' Rollers csapatba szerepeltetett egy női játékost is, egy kapust, aki a liga egyetlen nő tagja volt, MANON RHEAUMe-t (1995).

A Pánamerikai Játékokon 1979-ben mutatkozott be a görkorcsolyázás, mint új sport, a roller hockey labdás, görbe ütős változatával debütálva. A korongos verzió azonban jelentősebb mértékben növekedett, annak is az egysoros korcsolyával üzött formája, így 1999-ben a versenysorozat áttért a korongos, hosszú, jéghoki ütős verzióra.

\section{A görkorcsolya trükkök és táncfigurák kialakulása}

Bár a jégkorcsolyázás nem tárgya e cikknek, mégis fontos említést tenni a következő pár tényről, mert megjelennek a görkorcsolya versenyeken is. 1893-ban az ISU (International Skating Union) elhatározta, hogy rendez egy nemzetközi bajnokságot, de a szabályokat nem határozták meg elég precízen. A végső eredmény eldöntése meglehetősen vitás volt, ezért végül törölték a bajnokságot. A malőr után kidolgoztak egy korrekt pontozási rendszert. Az ugrásokat pl. a korszak legjobbjai által bemutatott ugrások határozták meg. A Norvégiából származó Axel Paulsenről nevezték el pl. az Axelt 1880-ban.

A svéd ULRICH SALCHOW neve után jött a Salchow ugrás 1910-ben, míg a német WeRnER RITTBERgER létrehozta a speciális csavart ugrását. Az osztrák ALOD's LUTz találta ki a később szintén róla elnevezett ugrást, de azóta sem ismert nagyon sokkal több erről a sportolóról. Meg kell jegyezni, hogy 1902-ban egy angol hölgy MADGE SYERS regisztrált és korcsolyázott is, mert a szabályokban elfelejtették kikötni, hogy hölgyek nem vehetnek

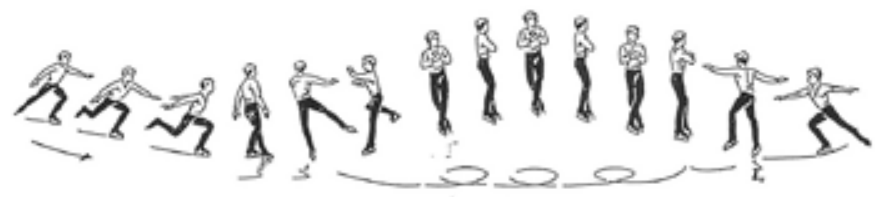

龱1 トリブル・アクセル・ジャンプの间棛

7. ábra A tripla Axel sorozatképe. A bírók a pontozáshoz elsősorban az elugrás mozdulatát, a forgás dinamikáját és a talajfogási pozíciót vizsgálják. Forrás: (Yoshioke, 1993)

részt a versenyen. Másodikként végzett, de a bajnokságot a következő évben már csak férfiaknak írták ki, azzal az átlátszó ürüggyel, hogy a Syers dressze túl hosszú volt elrejtette a láb mozdulatait a bírók szeme elöl. A hölgyeknek 1906-ig kellett várniuk, hogy kiírják az ő bajnokságukat is.

Az 1932-es Lake Placidben rendezett olimpia SonJA HeNIE részvételével újabb szíveket hódított meg a sport számára és

\footnotetext{
${ }^{19} \mathrm{http}: / /$ i.ebayimg.com/t/Vintage-Miniature-Wooden-Field-Hockey-Stick-AntiqueOld-/11/!CDoSH2!!Wk \$(KGrHqYOKjoE0,VHIs6FBNPNGDkqCg 0_3.JPG

${ }^{20}$ (Maddigan, 2009)
} 
komoly pénzekkel indított útjára egy újabb korcsolya őrületet. Az emberek belefáradtak az állandó néző szerepbe és nagy lelkesedéssel vetették magukat a korcsolyázás által nyújtott örömökbe, megtelve szenvedéllyel. A korizás akkor és most valami olyasmi, melyet bárki tud csinálni komolyabb anyagi, vagy idő ráfordítás nélkül is, ráadásul a korra jellemző depresszió sem tudta útját állni.

\section{Roller derby}

Az első világháború megálljt parancsolt a görkorcsolya őrületnek, ami később a késő 20-es és korai 30-as években tért vissza újra a görkori derbikkel (Skating Derbies), mint fö atrakcióval. A kifejezés derby - versenyt, vagy többszörös-verseny eseményt jelent, mely először 1922-ben jelent meg a sajtóban, amikor a Chicago Tribune közölte annak a két „roller derby”-nek az eredményeit, melyet abban az évben tartottak. Ezek többnapos események voltak, melyek során különféle görkorcsolya versenyeket rendeztek „flat track” azaz sík pályán, a chicagói Broadway Armory-n ${ }^{21}$. Egy pálya, 24 csapat, egy férfi és egy nő per csapat, egy hat napon át tartó versenyben. Alvás a ring közepére helyezett matracokon a nézők által is jól látható helyen. A hosz-

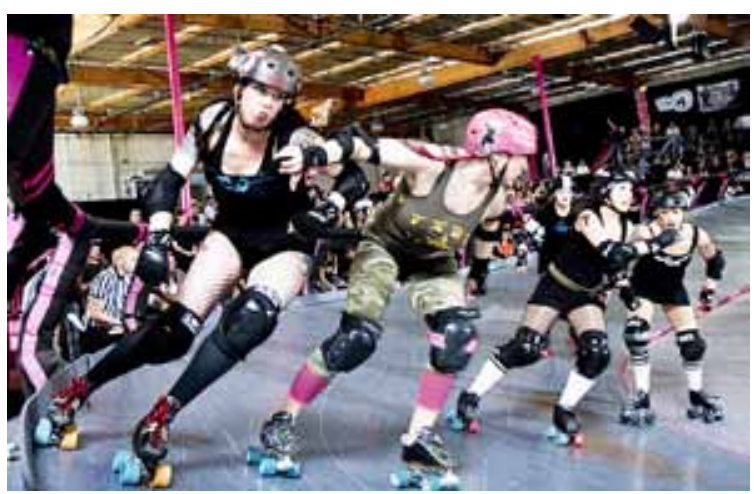

8. ábra Lökdösődés egy roller derby viadalon, egy döntött kanyarú körpályán (banked track) ${ }^{22}$

szú verseny során bemutatott sprintek apróbb pénzekkel voltak jutalmazva. Az első helyen végzett csapatot 1000, a harmadik 250 \$-ral jutalmazták.

A görkorcsolya mind jobb elterjedésével megnőtt a versenyek száma. A harmincas évek közepén már transzkontinentális Roller derbyket rendeznek.

\section{Görtánc, vagy müvészi görkorcsolyázás}

Eközben Európában csendben növekedett a görtánc népszerüsége és a késő harmincas évekig ugyan azon szabályok adta keretek között elérte úgy kecsességben és pontosságban a jégtánc színvonalát. 1938-ban a görtánc egy nemzeti verseny formájában megérkezett Amerikába is és hatalmas sikert aratott. Az amerikai szervezők, csak egy évvel korábban szerveződtek össze, tehát volt idejük alaposan felkészülni, így az esemény komoly érdeklődéssel zajlott.

A legtöbb ring akkoriban ajánlott már instrukciókat azoknak, akik el szerették volna sajátítani az alap, vagy a haladó mozdulatokat, mindegy hogy csak azért, hogy jobban korizzanak, vagy bajnokok legyenek. A ringek újra az elit legfelkapottabb szórakozó helyei lettek és egymásra licitálva túl szerettek volna tenni a másikon. Azzal versenyeztek, hogy kinek van jobb minőségü jávorfa parkettája, kinek van mindenből a legújabb felszerelése stb. Még a jól bevált kiszolgáló személyzet is sorra visszahívták.

1939-ben az első görkorcsolya táncbajnokságot New Yorkban rendezték, majd ugyanebben az évben, Gardens pályán (Detroit) rendezték az első gör-show bajnokságot.

A korai 1940-es években a bajnok korcsolyázók járták az országot és jégrevükben mutatták be tudásukat. A második világháború kitörése ezúttal pont ellentétesen hatott a korcsolyázásra. Sok ezer besorozottat és szolgálatost, csak úgy mint a civil lakosságot hivatalosan is bátorították, hogy korcsolyázzon a fittebb fizikai színvonalra törekvés érdekében.

Ami a korcsolyákat illeti a Chicago Sktates Co. - mely quadjaival megrázta az ipart, - meglepő módon 1960-as évekig értékesíteni próbált egysoros korcsolyáik nem hoztak átütő sikert. Az egysorosok nem igazán rúgtak labdába akkor, amikor a komoly figurák kivitelezésére került sor.

\section{A Rollerblade történetének állomásai $23,24,25$}

A soros görkorcsolya újabb felvirágzása a 70-es évek végére tehető. A fejlesztésére ebben a korszakban is történnek kísérletek, több szabadalom kerül bejelentésre. Ilyen volt pl. MoRRIS L. SILVER 1973-as Tandem Roller Hockey Skate elnevezésü korcsolyája, vagy Ronald G. CARLSON 1974-es soros Roller Skate-je, ill. David B. Agins 1976-os Wheel with molded tire for cart fantázianevü találmánya, mely egy hálózatos központú csillapított targonca kerék volt, mely később alapot szolgáltatott a kori kerekek tervezéséhez.

Az egysoros, vagy inline korcsolya tulajdonképpeni sikeréért azonban két amerikai jéghokis a felelős, akik a hoki szezonon kívüli nyári edzéslehetőségen törték a fejüket, amikor egy használt sporteszközöket árusító bolt (Sporting goods) leértékelt holmikkal telerakott ládájában rábukkantak egy pár korai soros görkorcsolyára. A modellt valamikor a korábban említett

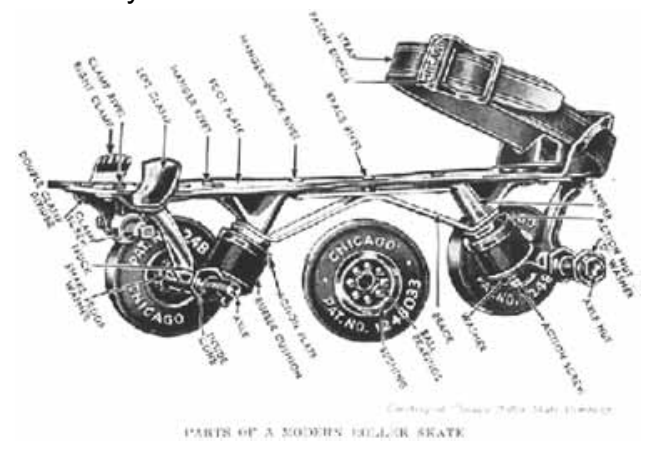

9. ábra A Chicago Skate Co. által készített a két világháború között legnépszerübb görkorcsolyája. Forrás: (Rink, 2011)

\footnotetext{
21 (Wikipedia, 2012)

22 (Losanjealous, 2013)

23 (Karmelek, 2012)

${ }^{24}$ (Roller skating, 2013)

${ }^{25}$ (SkateSetup.Com, 2011)
} 
Chicago Skate Company gyártotta. A szerkezet alig fogta a bokát, a kerekei pedig egyszerüen csapnivalóak voltak.

Ezek felhasználásával 1979-ben az Olsen fivérek Scotr és BRENNAN, minneapolisi házuk alagsorában elkészítették az első, később komoly üzleti sikereket hozó inline (egysoros) görkorcsolyát. Az elkészült korit Rollerblade-nek nevezték el. Minnesota utcáin hamarosan jéghoki játékosok, sízők, sífutók tủntek fel Rollerblade görkorcsolyákkal a lábukon. ${ }^{26}$

A késő nyolcvanas és a korai kilencvenes évek a Rollerblade márkanévvel fémjelzett korcsolyák olyan sikeresekké váltak,

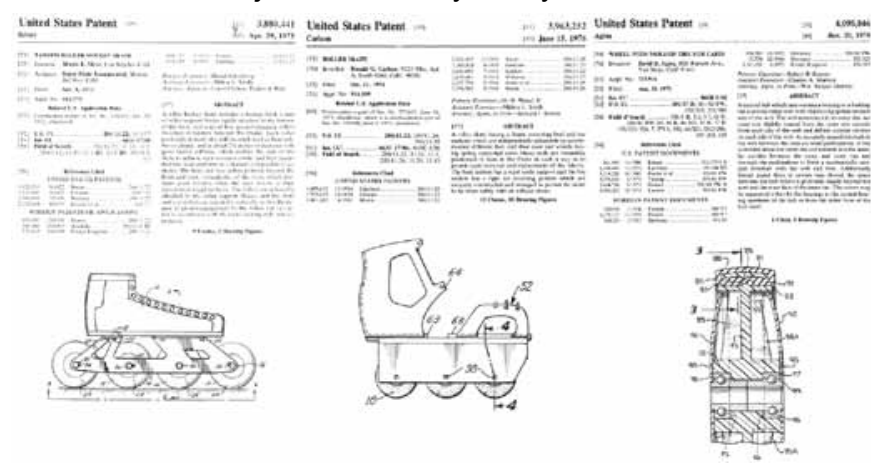

10. ábra államokbeli szabadalmi szám 3880441, 3963252, 4095846 - A kép forrása: (Mitskevichus,

Очерки по истории изобретений, 2011)

hogy sok más vállalatot is arra inspiráltak, hogy hasonló görkorcsolyákat hozzanak létre és ezzel az egysoros dizájn még népszerübb lett, mint a hagyományos párhuzamos quad korik. Persze ez nem csak a véletlennek volt köszönhető. A stratégiai marketing erőfeszítések meghozták gyümölcsüket, hiszen a márkanév a köztudatba került, olyannyira, hogy angol nyelvterületen a Rollerblade általános elnevezése, szinonimája lett az egysoros görkorcsolyának. ${ }^{27} \mathrm{Az}$ emberek, ha korizni indultak egysoros korcsolyájukkal, már így fejezték ki magukat - megyek Rollerblédezni (Rollerblading) ${ }^{28}$.

A két fivér folyamatos fejlesztésekkel javítottak a szerkezeten, ugyanis az első tömegtermelésben készült korcsolyájuk nem volt hibátlan. Ilyenek bosszantó probléma volt például, hogy rendkívül nehezen lehetett őket felvenni és beállítani, a csapágyak hajlamosak voltak hamar elkoszolódni, a kerekek könnyen sérültek, ill. a fék még az öreg párhuzamos korik orr féke volt, s mint ilyen nem volt túl hatékony. A fejlesztések között szerepelt továbbá, hogy megerősítették a bokarészt, és poliuretánból készült kerekekkel látták el az újabb garnitúrát stb.

Az első Rollerblade görkorcsolyák valójában soros „alvázzal" szerelt hoki cipök voltak. Manapság közel hatvan egysoros görkorcsolyát gyártó cég van, de a Rollerblade hozta ki (az egyébként jóval korábban feltalált) sarokfék továbbfejlesztett változatát, az Aktív Fék Technológiát (ABT, Active Brake Technology), mely a fékezést könnyebbé, ill. jobban tanulhatóbbá teszi. A Rollerblade közel 200 szabadalommal és 16 regisztrált védjeggyel büszkélkedhet. ${ }^{29}$

A testvérek végül úgy döntöttek, hogy megveszik a Chicago Skate Company-tól a soros görkorcsolyák szabadalmát, és lét-

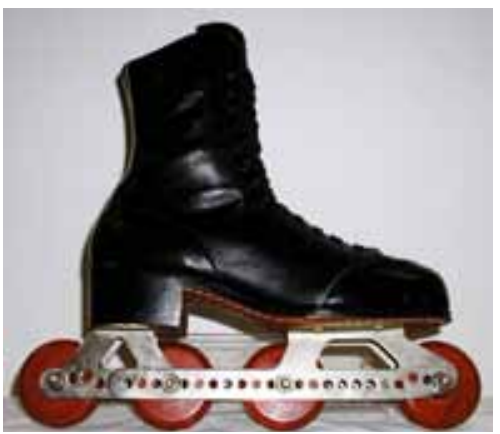

11. ábra A Cicago Skate Company által 1966-ban gyártott egysoros görkorcsolya, mely a Rollerbladek ihletője lehetett Forrás: (National Museum of Roller Skating, 2010)

rehozzák a Rollerblade Company-t, ám 1983-ban ScotT OLSEN eladja a céget egy helyi üzletembernek, RoBERT NAGLE-nek. A friss tőkeinjekciónak köszönhetően új és jobb korcsolyákat tudtak fejleszteni, és megkezdődött a sporteszközök történetében páratlan meredekséggel felfelé ívelő karrier. 1989-re már évente hárommillió pár egysoros görkorcsolyát adnak el. Nemsokára újabb típusok jelennek meg.

Az első igen sikeres Rollerblade görkorcsolya a Lightning TRS lett (12. ábra). Ezen a korcsolyán a hiányosságokat és hibákat kiküszöbölték. Üvegszálból készült a keret és a sín, a kerekek sokkal jobb védelemmel lettek ellátva, a cipőrész könnyebben kezelhető, felvehető lett és az erősebb fékeket, melyet kapott, immár hátulra helyezték. A TRS sikerei okán más gyártók, e modellt etalonként fogadták el (Ultra Wheels, Oxygen, K2 és mások).

A Rollerbalde, Inc. azonban nem áll meg a fejlesztésekkel és 1989-ben létrehozta a Macro és Aeroblade modellt, az első három csattal meghúzható görkorcsolyát, ezzel egyszerübbé téve a körülményes cipőfüzővel való „operálást”.

Újabb jelentős elörelépést érnek el a gyártásban, mikor 1990ben a korcsolyák anyagát (polyurethane keverék) drasztikusan megváltoztatva áttérnek az üvegszállal megerősített termoplasztikus müanyagra (durethen polyamide). Ezzel a lépéssel közel $50 \%$-al csökkent az átlagsúly.

A korábban már említett fékrendszert, az ABT-t technológiát 1993-ban fejlesztik ki, melynek lényege a biztonságosabb fékezés. Kialakítását tekintve a fejlesztők egy üvegszál nyúlványt rögzítettek a cipőszár hátsó részének tetejére, melynek másik vége a gumituskóhoz rögzül, mely a hátsó kerék mögött kapcsolódik a sínhez így a tuskó egy csuklón el tud fordulni. A görkorcsolyázónak ki kell nyújtania a térdét a fékezéshez, mely mozdulat hatására a cipő szár, az arra rögzített nyúlványt a fékbe vezeti, amely emiatt a földre nyomódik. A korisoknak az $A B T$ előtt hátra kellett billenteniük a lábukat, ha a gumituskót a földnek akarták nyomni, ami azért volt veszélyes, mert a korcsolyázó tömegközéppontja a hátsó kerék mögé kerülhetett, ami óhatatlanul is hanyatt eséssel végződik. Az új technológia miatt tehát megnőtt a biztonság.

A sielök is felfedezik, hogy ezzel az új eszközzel a betonon is

${ }^{26}$ (Karmelek, 2012)

27 (Karmelek, 2012)

${ }^{28}$ (Roller skating, 2013)

${ }^{29}$ (Karmelek, 2012) 

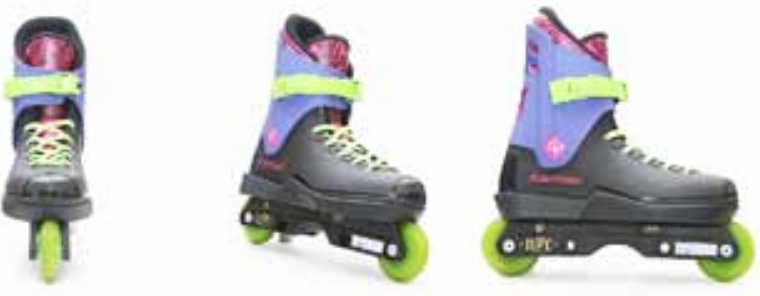

12. ábra A Lightning TRS az első igazán elsöprő sikerü újkori inline görkorcsolya az Rollerblade-töl. ${ }^{30}$

meredek kanyarokat vehetnek, így belőlük alakul ki a második legnagyobb vásárló réteg, amely kiegészítő sportágként kezdi használni a soros görkorikat. Az egysoros görkorcsolyázás hamarosan az egész sísport által erősen támogatott és ajánlott nyári edzésmódszer lesz.

Egy másik igen lelkes és népes tábor, mely a soros görkorcsolyában találta meg álmai sporteszközét, a nyolcvanas években dúló aerobik és fitnesz divat követőiből került ki. A fit-
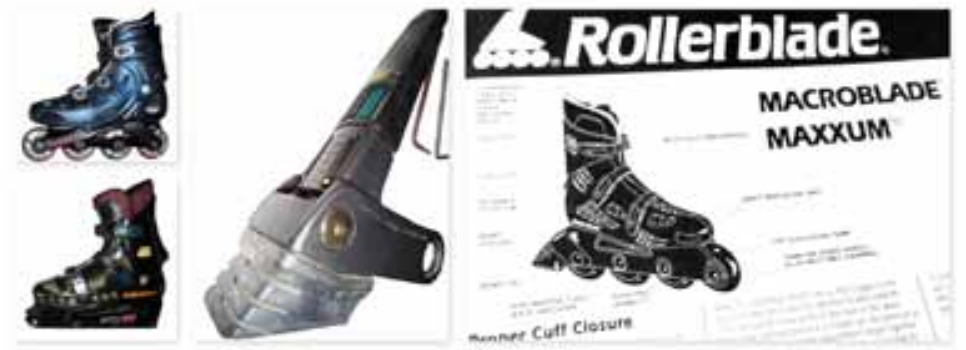

13. ábra Rollerblade Macro (bal felül) és Aeroblade (bal alul) és az ABT fékrendszer

nesz fanatikusai hamar rájöttek, hogy a korcsolyázás a lábak és a fenék formában tartásának egyik legjobb módszere, és a futásnál sokkal kisebb mértékben veszi igénybe az ízületeket.

Ebben az időszakban a görkorcsolyák föként általános hétköznapi használatra készültek és adták el őket, leginkább kemény mủanyag, a síbakancshoz hasonlatos cipő részeket alkalmazva. 1995-töl kerültek forgalomba az ún. „soft boot”

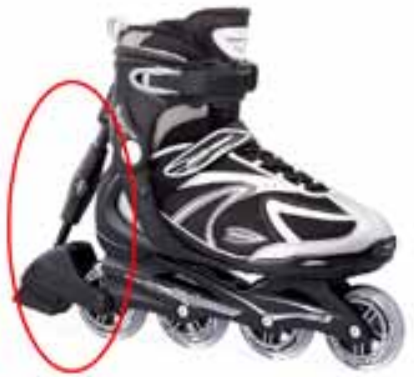

14. ábra $A$ Rollerblade féle új fék az $A B T$, melyet 1993-ban fejlesztettek ki.

(puha cipős) kialakítású korik, melyeket először a „Sporting good" jelmondatú K2-es cég, fitnesz korcsolya elnevezéssel promótált (Érdekes összefüggés, hogy ugyan ez volt annak a kis sportboltnak a neve, ahol az Olsen fivérek rátaláltak arra a korai soros görkorcsolyára, amelyböl kiindult az inline görkorcsolya őrület.). A többi gyártó gyorsan követte e megoldást és a

\footnotetext{
${ }^{30}$ (SkateSetup.Com, 2011)
}

korai 2000-es évekre a kemény héjú kialakítással gyártott korcsolyákat már „agresszív egysoros görkorcsolya” elnevezéssel futottak, melyek később egyéb más speciális dizájnnal is megtoldottak ${ }^{12}$.

\section{Folytatás a Görkorcsolyázás története IV. cikkben.}

\section{IRODALOMJEGYZÉK}

» Roller skating. (2013). Letöltés dátuma: 2013. 01 08, forrás: https://www.facebook.com/pages/Roller-skating/10928707908 9330?fref=ts\&_req=2n\&rf=108612202502507\#: https://www. facebook.com/pages/Roller-skating/109287079089330?fref=ts\&_ req $=2 \mathrm{n} \& \mathrm{rf}=108612202502507 \#$

» Béres, S. (2012. 09). A görkorcsolyázás története I. Recreatio. eu(2012. 09. II. évfolyam 3. szám.)

" Béres, S. (2012. 12). A görkorcsolyázás története II. (D. Erika, Szerk.) recreacio.eu(4.), old.: 21.-27.

» Bonnefon, R. (2005. 02 21). Bienvenue sur la page de patinage de REB, History. Letöltés dátuma: 2012. 03 05, forrás: http://regisbonnefon.chez-alice.fr: http://regis-bonnefon.chez-alice.fr/histoire-en. html

» Fixed Gear Gallery. (2013. 01 24). Fixed Gear Gallery. Letöltés dátuma: 2013. 01 30, forrás: https://www.facebook.com/ FixedGearGallery?fref=ts: https://www.facebook.com/photo.php?fbid= 10151175709036710\&set=a.241478651709.146493.44058811709\&ty pe=1\&theater

» Granger. (2013). Vaudville Theather, c1905. Letöltés dátuma: 2013. 01 25, forrás: http://images.fineartamerica.com: http://images. fineartamerica.com/images-medium-large/vaudeville-theatre-c1905granger.jpg

» Karmelek, M. (2012. 03 19). Over 100 Years Later, an Old Invention Takes a New Spin. Letöltés dátuma: 2012. 03 29, forrás: http://blogs. scientificamerican.com/anecdotes-from-the-archive/: http://blogs. scientificamerican.com/anecdotes-from-the-archive/2012/03/19/over100-years-later-an-old-invention-takes-a-new-spin/ " Losanjealous. (2013). Losanjealous. Letöltés dátuma: 2013. 01 29, forrás: http://www.losanjealous.dreamhosters. com/2008/07/03/a-derby-smorgasbord-ii/: http://farm4.static.flickr. com/3124/2628855923 793f7901bf.jpg?v=0

» Maddigan, M. (2009. 05 21). Roller Polo. Letöltés dátuma: 2013. 01 29, forrás: http://nemasket.blogspot.hu: http://nemasket.blogspot. hu/2009/05/roller-polo.html

»Mitskevichus, А. (2011. 04 16). Очерки по истории изобретений. Letöltés dátuma: 2012. 02 02, forrás: http://top100invent.blogspot. com/: http://top100invent.blogspot.com/2011/04/p-roller-skates.html » National Museum of Roller Skating. (2010). The history of inline skating at the National Museum of Roller » Skating. Letöltés dátuma: 2013. 01 24, forrás: http://www.rollerskatingmuseum.com: http://www. rollerskatingmuseum.com/inline.html

» Rink, C. R. (2011. 10 05). Roll On!!!! Letöltés dátuma: 2013. 01 24, forrás: http://www.cairopurlingrollerrink.com/: http://www. cairopurlingrollerrink.com/rollon.html "SkateSetup.Com. (2011). Thisissoul Custom 1988 Rollerblade. Letöltés dátuma: 2013. 01 09, forrás: http://www.skatesetup.com/: http://www.skatesetup.com/Skates/Rollerblade/Non-UFS/ThisissoulCustom-1988-Rollerblade--4598

» Wikipedia. (2012. 10 16). History of roller derby. Letöltés dátuma: 2013. 01 28, forrás: http://en.wikipedia.org: http://en.wikipedia.org/ wiki/History_of_roller_derby

" Yoshioke, N. (1993). Figure Skating Triple Axel Paulsen Jump. Letöltés dátuma: 2013. 02 04, forrás: http://iocsse.tnoken.com/Panel_number/007_Triple_Axel/007_E.html: http://iocsse.tnoken.com/ Panel_number/007_Triple_Axel/007img/007-2 